\title{
Successful treatment of collagenous sprue with combination of prednisolone and gluten-free diet
}

\author{
D. J. Holdstock* \\ M.Sc., M.D., M.R.C.P.
}

\author{
SAMuel OleEsky \\ M.Sc., M.D., F.R.C.P.
}

M.3 Unit, Manchester Royal Infirmary, Manchester

\section{Summary}

A case is described of adult coeliac disease with subepithelial collagen in a jejunal biopsy ('collagenous sprue') which responded well to treatment with prednisolone in addition to a gluten-free diet. The indications for corticosteroid treatment in adult coeliac disease are discussed in the light of the findings. It is suggested that collagenous sprue may represent the most severe form of adult coeliac disease, and the presence of sub-epithelial collagen in a jejunal biopsy may be the strongest indication for treatment with the combination of a gluten-free diet and corticosteroids.

\section{Introduction}

The majority of patients with adult coeliac disease respond well to a gluten-free diet (French, Hawkins \& Smith, 1957; Shiner, 1963; Pink \& Creamer, 1967). However, a proportion of patients remain unwell in spite of strict adherence to the diet. Some such patients are helped by corticosteroid therapy, but a few go on to a fatal outcome (French et al., 1957; Badenoch, 1960; Pink \& Creamer, 1967). Several fatal cases have been reported in which subepithelial collagen was present in an intestinal biopsy (Schein, 1947; Hourihane, 1963; Barry, Morris \& Read, 1970; Weinstein et al., 1970; Doe et al., 1972; Dowling \& Henry, 1972) and it has been suggested that 'collagenous sprue' may represent a separate entity (Weinstein et al., 1970). Small foci of collagen are seen in up to $40 \%$ of jejunal biopsies in adult coeliac disease (Cooke et al., 1963; Hourihane, 1963), but in combination with such features as hypoproteinaemic oedema 'collagenous sprue' has had a fatal outcome in those cases which have been reported in detail. We therefore report here a patient with severe adult coeliac disease, with marked subepithelial collagen in a jejunal biopsy, who has been maintained in good health by the combination of corticosteroid therapy and a gluten-free diet.

\footnotetext{
* Correspondence and requests for reprints to: Dr D. J.
} Holdstock, Ashford Hospital, Middlesex TW15 3AA.

\section{Case report}

This patient has been briefly described previously (Holdstock \& Oleesky, 1970). A 50-year-old housewife in 1967 was found elsewhere to be anaemic with evidence of folate and iron deficiency, and later developed diarrhoea and hypoalbuminaemia with low urinary D-xylose excretion. She was placed on a gluten-free diet but did not completely adhere to this. When seen here in October 1968 she was critically ill with loss of weight, diarrhoea (faecal fat $15 \mathrm{~g} /$ day), ascites and hypoproteinaemic oedem (serum albumin $2.1 \mathrm{~g} / 100 \mathrm{ml}$, globulin $1.4 \mathrm{~g} / 100 \mathrm{ml}$ ) Serum $B_{12}$ was low $(50 \mathrm{pg} / \mathrm{ml})$ and there was evie dence of protein-losing enteropathy, with $25 \%$ of $100 \mu \mathrm{C}^{51} \mathrm{CrCl}_{3}$ lost in stools in 5 days (normal $<1 \%$ Walker-Smith, Skyring \& Mistilis, 1967). A jejunal biopsy on 7 November, 1968, showed subtotal villous atrophy, with very severe damage to the enterocytes, which were absent in some areas, and prominent subepithelial collagen (Fig. 1).

A period of treatment with a strict gluten-free diet, replacement therapy and diuretics produced no

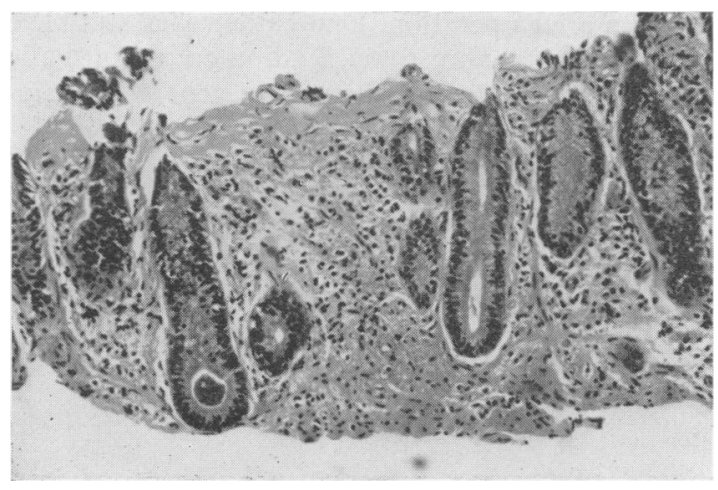

Fig. 1. Jejunal biopsy, before treatment with prednisolone, showing subtotal villous atrophy, with extensive subepithelial collagen and severe damage to and loss of enterocytes. 


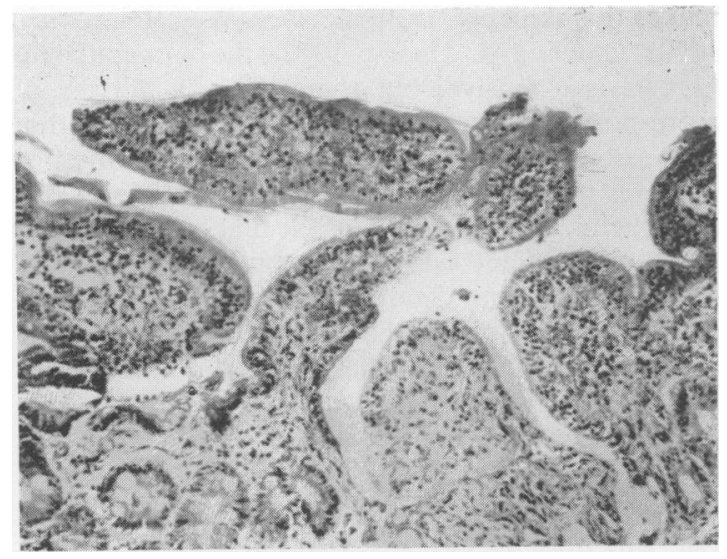

Fig. 2. Jejunal biopsy, during treatment with prednisolone and gluten-free diet, showing partial villous atrophy with no subepithelial collagen.

improvement and she was therefore given prednisolone $30 \mathrm{mg}$ daily from 4 December 1968 . This produced considerable improvement, with clearing of the ascites and oedema and a rise in serum proteins (serum albumin $3.7 \mathrm{~g} / 100 \mathrm{ml}$, globulin $2 \cdot 2 \mathrm{~g}$ / $100 \mathrm{ml}$ ). On 17 March 1969 a repeat jejunal biopsy now showed only partial villous atrophy with no abnormal collagen (Fig. 2), and prednisolone dosage was reduced to $15 \mathrm{mg}$ daily, but hypoproteinaemia recurred (serum albumin $1.9 \mathrm{~g} / 100 \mathrm{ml}$, globulin $1.8 \mathrm{~g} / 100 \mathrm{ml}$ ) and there was again evidence of intestinal protein loss $\left(9 \%\right.$ of dose of i.v. $\left.{ }^{51} \mathrm{CrCl}_{3}\right)$. In July 1969 she developed a generalized dermatosis thought to be pemphigus erythematosus (Dr G. Auckland), and a skin biopsy showed vasculitis. Prednisolone dosage was increased to $40 \mathrm{mg} /$ day and she improved again, though improvement was interrupted by several grand mal fits. By November 1969 serum proteins had returned to normal (serum albumin $4.0 \mathrm{~g} / 100 \mathrm{ml}$, globulin $3.5 \mathrm{~g} / 100 \mathrm{ml}$ ). Since then she has remained well on a gluten-free diet, folic acid, and anticonvulsants, and the dosage of prednisolone has been cautiously reduced to $15 \mathrm{mg}$ daily. Her haemoglobin is $13.5 \mathrm{~g} / 100 \mathrm{ml}$ and serum proteins are normal; albumin $4 \cdot 2 \mathrm{~g} / 100 \mathrm{ml}$ and globulin $2 \cdot 3 \mathrm{~g} / 100 \mathrm{ml}$.

\section{Discussion}

The majority of patients with adult coeliac disease improve on a gluten-free diet, but a minority fail to respond and may even continue to deteriorate; in the series reported by Pink \& Creamer (1967) $70 \%$ of their patients improved on the diet, but five became worse, two of whom died. Histological improvement in jejunal morphology may not match clinical and biochemical improvement (Shiner, 1963). Steroid therapy is helpful in some of these cases which do not respond to the diet; three of Pink \& Creamer's patients improved on the combined therapy.

Treatment with corticotrophin or corticosteroids was successful in idiopathic steatorrhoea before the introduction of the gluten-free diet (Aldersberg, Colcher \& Drachman, 1951; Cooke, 1953; Lepore, 1958; Brown, Glasser \& Kurt, 1959). Oral prednisolone alone causes improvement in the histological, histochemical and biochemical, as well as the clinical, features of patients subsequently shown to respond to a gluten-free diet (Wall et al., 1970); these authors suggest that it may act by stabilizing lysosomal membranes. Clearly only the most severely affected cases are likely to need corticosteroid treatment in addition to a gluten-free diet; in these villous atrophy will extend into the ileum (MacDonald et al., 1964; Stewart et al., 1967). Involvement of the ileum is indicated by a low serum $B_{12}$ level or by the Schilling test (Stewart et al., 1967). Other findings suggesting extensive disease with the possibility of a poor response to the diet alone include proteinlosing enteropathy and 'collagenous sprue'.

\section{Protein-losing enteropathy}

Hypoalbuminaemia has been a feature of severe, and particularly fatal, cases of adult coeliac disease (Pink \& Creamer, 1967; Barry et al., 1970; Weinstein et al., 1970; Doe et al., 1972; Dowling \& Henry, 1972). It was a marked feature in our patient, in whom the cause was protein-losing enteropathy. This may be related both to the extent of the mucosal lesion and to its severity, with actual loss of enterocytes in some areas (Fig. 1). Intestinal ulceration in coeliac disease has been reported several times (Barry et al., 1970; Doe et al., 1972; Dowling \& Henry, 1972); this ulceration may progress to stricture formation and perforation, often with a fatal outcome (Bayless et al., 1967). It seems to be a true complication of coeliac disease, and has been reported in association with protein-losing enteropathy (London, Bamforth \& Creamer, 1961; Dowling \& Henry, 1972). Ulceration does not seem to respond to steroid therapy when strictures have formed (Bayless et al., 1967). However, the loss of enterocytes seen in the jejunal biopsy in our patient (Fig. 1) may be the earliest stage of the process, when steroid therapy might still be successful.

\section{Collagenous sprue}

The presence of a layer of hyaline material staining for collagen beneath the enterocyte layer is a feature common to some recent detailed reports of fatal cases of malabsorption (Barry et al., 1970; Weinstein et al., 1970; Doe et al., 1972; Dowling \& Henry, 1972). All these failed to respond to a gluten-free diet at some stage of their illness, though Doe 
and colleagues' case was controlled by the diet for some years, and the ultimately fatal relapse may have followed the accidental administration of gluten in Nulacin tablets. These patients may be particularly sensitive to gluten; the patient of Dowling \& Henry (1972) also relapsed after accidental administration of gluten, and our patient admitted to occasional lapses from the diet in the earlier stages of her illness. In some patients with adult coeliac disease, presumably those less severely affected, such occasional lapses are not incompatible with a satisfactory response to the diet (Pink \& Creamer, 1967), and a trial of gluten-reintroduction has been used as a diagnostic measure in adult coeliac disease; this may be dangerous and strongly contraindicated in the type of patient reported here. It is not certain that all the reported cases have true coeliac disease; Barry et al. (1970) comment that their patient was atypical in that the enterocytes in the jejunal biopsy were relatively normal and cell loss into the intestinal lumen was reduced, though their patient had been on a gluten-free diet for some time at the time of biopsy. Their patient also had active tuberculosis and was not given corticosteroids. Both Doe and colleagues', Weinstein's, and Dowling \& Henry's patients were given prednisolone in combination with a gluten-free diet at some stage, though the diet was withdrawn fairly early in Weinstein's patient. Two other fatal cases with similar histological findings have also been reported by Schein (1947), antedating both corticosteroid therapy and the gluten-free diet, and by Hourihane (1963), who gives no details of clinical features or treatment.

Doe and colleagues' (1972) patient with 'collagenous sprue' (their Case 4) was one of four with vasculitis and cryoglobulinaemia; another of their patients also died in spite of steroid therapy, but had no evidence of collagenous sprue. Our patient also had vasculitis in a skin biopsy, though cryoglobulins were not detected and serum immunoglobulins were normal at a time when she was clinically well on prednisolone $30 \mathrm{mg}$ daily and a gluten-free diet. Vasculitis complicating coeliac disease may be a further indication for combined treatment with prednisolone and a gluten-free diet.

There is evidence that sub-epithelial collagen may appear during the course of the illness in patients with collagenous sprue; both Weinstein's and Doe and colleagues' patients had had previous biopsies which showed typical subtotal villous atrophy but had no abnormal collagen. No case has previously been reported in which the abnormal collagen has disappeared in a later biopsy as in our patient (Fig. 2); this could of course be a sampling artefact, but the overall appearance of the second biopsy and the associated improvement in the patient's condition makes this unlikely. In fatal cases (Weinstein et al., 1970; Dowling \& Henry, 1972) the sub-epithelial $\stackrel{2}{\circ}$ fibrosis is extensive, but there are small areas of $c$ more normal mucosa; it is perhaps surprising that $\vec{F}$ such extensive fibrosis can disappear in a few months $\stackrel{5}{\stackrel{5}{9}}$ as seems to have occurred in our patient. No special ? histochemical examination of the first biopsy (Fig. 1) 을 from our patient was made, but Weinstein and $\frac{D}{D}$ colleagues present detailed evidence that the sub- $\stackrel{\mathbb{D}}{\Omega}$ epithelial deposit is indeed collagen.

Small foci of subepithelial collagen may be found in up to $40 \%$ of jejunal biopsies (Cooke et al., 1963; Hourihane, 1963), but our patient appears to be the $\vec{\omega}$ first reported case with extensive subepithelial collagen to survive in good health, and we suggest 6 that this may be due to the combination of a strict gluten-free diet with prednisolone in high dosage $\overrightarrow{0}$ (30-40 mg daily). There seems to be a spectrum of or severity in adult coeliac disease, with malabsorption of of vitamin $B_{12}$, protein-losing enteropathy, ulceration and extensive subepithelial collagen indicating an increasing degree of severity. Not all cases with $\frac{}{5}$ malabsorption of vitamin $\mathbf{B}_{12}$ may need cortico- $\vec{C}$ steroid treatment, but hypoalbuminaemia and exten- $\mathbb{D}$ sive collagen in the jejunal biopsy indicate the need $\frac{\vec{D}}{\mathbb{D}}$ for high dosage of corticosteroids in combination 3 with strict gluten deprivation in the early stages, $\mathbb{D}$ with very cautious reduction in steroid dosage when $\overrightarrow{0}$ the patient's condition improves.

\section{References}

Adlersberg, D., Colcher, H. \& Drachman, S.R. (1951) Studies on the effects of cortisone and pituitary adreno- $\bar{O}$ corticotrophic hormone (ACTH) in the sprue syndrome. Gastroenterology, 19, 674.

BADENOCH, J. (1960) Steatorrhoea in the adult. British Medical Journal, 2, 879.

BARRY, R.E., MORRIS, J.S. \& ReAD, A.E.A. (1970) A case of small intestinal mucosal atrophy. Gut, 11, 743.

BAYless, T.M., KAPELOWITZ, R.F., Shelley, W.M., BallinGER, W.F. \& HENDRIX, T.R. (1967) Intestinal ulcerationa complication of coeliac disease. New England Journal of $\mathrm{O}$ Medicine, 276, 996.

Brown, C.H., Glasser, O. \& KuRT, E.J. (1957) Radioactive $\bar{\sigma}$ fat absorption and clinical response of sprue to steroid 3 therapy. Gast roenterology, 36, 760.

COOKE, W.T. (1953) The effect of corticotrophin in idio- $\frac{0}{3}$ pathic steatorrhoea. Lancet, ii, 425.

CoOKe, W.T., Fone, D.J., CoX, E.B., MeYnell, M.J. \& 윽 GADDIE, R. (1963) Adult coeliac disease. Gut, 4, 279.

Doe, W.F., Evans, D., Hobbs, J.R. \& Booth, C.C. (1972) Coeliac disease, vasculitis and cryoglobulinaemia. Gut, 13, 112.

Dowling, R.H. \& HeNRY, K. (1972) Non-responsive coeliac ${ }^{-}$ disease. British Medical Journal, 3, 624.

FrenCH, J.M., HaWkins, C.F. \& SMITH, N. (1957) The effect N of a wheat-gluten-free diet in adult idiopathic steatorrhoea. $\omega$ Quarterly Journal of Medicine, 26, 481.

HolDSTOCK, D.J. \& OLEESKY, S. (1970) Vasculitis in coeliaøo disease. British Medical Journal, 4, 369.

HOURIHANE, D.O'B. (1963) The histology of intestinal $\mathbb{D}$ biopsies. Proceedings of the Royal Society of Medicine, 56, 1073. 
LEPORE, M.J. (1958) Long-term or maintenance adrenal steroid therapy in non-tropical sprue. American Journal of Medicine, 25, 381.

London, D.R., BAmforth, J. \& CREAmer, B. (1961) Steatorrhoea presenting with gastrointestinal protein loss. Lancet, ii, 18.

MacDonald, W.C., Brandborg, L.L., Flick, A.L., Trier, J.S. \& Rubin, C.E. (1964) Studies of coeliac sprue. IV. The response of the whole length of the small bowel to a gluten-free diet. Gastroenterology, 47, 573.

Pink, I.J. \& Creamer, B. (1967) Response to a gluten-free diet of patients with the coeliac syndrome. Lancet, $\mathbf{i}, 300$.

SCHEIN, J. (1947) Syndrome of non-tropical sprue with hitherto undescribed lesions in the small intestine. Gastroenterology, 8, 438.
SHINER, M. (1963) Effect of a gluten-free diet in seventeen patients with idiopathic steatorrhoea: a follow-up study. American Journal of Digestive Diseases, 8, 969.

Stewart, J.S., Pollock, D.J., Hoffbrand, A.V., Mollin, D.L. \& Booth, C.C. (1967) A study of proximal and distal intestinal structure and absorptive function in idiopathic steatorrhoea. Quarterly Journal of Medicine, 36, 425.

WAlker-Smith, J.A., Skyring, A.P. \& Mistilis, S.P. (1967) Use of ${ }^{51} \mathrm{CrCl}_{3}$ in the diagnosis of protein-losing enteropathy. Gut, 8, 166.

Wall, A.J., Douglas, A.P., Booth, C.C. \& Pearse, A.G.E. (1970) Response of the jejunal mucosa in adult coeliac disease to oral prednisolone. Gut, 11, 7 .

Weinstein, W.M., Saunders, D.R., Tytgat, G.N. \& Rubin, C.E. (1970) Collagenous sprue-an unrecognised type of malabsorption. New England Journal of Medicine, 283, 1297.

\title{
Ankylosing spondylitis and auto-immunity
}

\author{
G. O. CowaN \\ M.B., M.R.C.P., M.R.C.P.E., D.T.M.\&H. \\ British Military Hospital, Rinteln B.F.P.O.29
}

\begin{abstract}
Summary
A case of ankylosing spondylitis is described in which a relationship with gastric and endocrine autoimmunity could be demonstrated.
\end{abstract}

\section{Case report}

C.B., a Caucasian male aged 46, presented with a history for 4 months of general malaise, night sweats, loss of $8 \mathrm{~kg}$ in weight and deep constant pain in both hips, lower central back and upper lateral chest, with associated morning stiffness and considerable loss of spinal mobility. He admitted to occasional slight backache for 10 years, but he had never previously sought treatment for it. He had no peripheral joint pain and no gastro-intestinal or urinary symptoms.

On examination, he had marked loss of spinal mobility, being unable to rise from a supine position without first rolling prone. There was marked tenderness over both sacro-iliac joints and generally over his spine and rib-cage. Cervical spinal mobility was good. There was no evidence of peripheral joint disease and examination of his central nervous system, abdomen, heart and eyes was normal. Chest expansion was limited to $2 \mathrm{~cm}$, but his peak expiratory flow rate was $4101 / \mathrm{min}$. Rectal examination revealed a slightly enlarged and markedly tender prostate gland, especially in the medial lobe.

Investigations. Significant abnormal findings were: ESR (Westergren) $85-120 \mathrm{~mm} / \mathrm{hr}$; total serum proteins $7.4 \mathrm{~g} / 100 \mathrm{ml}$, albumin $3.0 \mathrm{~g} / 100 \mathrm{ml}$, globulin
$4.4 \mathrm{~g} / 100 \mathrm{ml}$, with no abnormality on paper electrophoresis but moderately raised IgG level $(1 \cdot 7 \mathrm{~g} /$ $100 \mathrm{ml}$ ). Auto-antibodies (Doniach, personal com munication): thyroglobulin tanned cell agglutinationo negative; cytoplasmic immunofluorescent antibodies positive (CFT 1 in 4); gastric parietal cell antibodies strongly positive; adrenal antibodies negative; antinuclear factor negative.

Serum $B_{12} 125 \mathrm{pg} / \mathrm{ml}$. (Euglena gracilis). Schilling test $\left(1 \mu \mathrm{g}\right.$ of $\left.58 \mathrm{Co} \mathrm{B}_{12}\right)$ less than $1 \%$ absorbed in $24 \mathrm{hr}$ without intrinsic factor; $25 \%$ absorbed in $24 \mathrm{hr}$ with intrinsic factor. Maximal histamine test $(0.04 \mathrm{mg} / \mathrm{kg})$ : no free acid in gastric contents before or in $1 \mathrm{hr}$ after injection. Gastric biopsy: marked thinning of the mucous membrane, shortening of gastric glands, marked plasma cell and lymphocyte infiltration of lamina propria.

Haemoglobin $13.2 \mathrm{~g} / 100 \mathrm{ml}$, PCV $42 \%$. Sternal marrow biopsy: normoblastic erythropoiesis but reduced stained iron. Serum iron $100 \mu \mathrm{g} / 100 \mathrm{ml}$. X-rays: chest and skull normal. Lumbar spine: marked bilateral sacro-iliac joint sclerosis with anterior and posterior lumbar intervertebral spondylitis and syndesmophytes. Slight posterior intervertebral sclerosis in upper dorsal spine. Barium meal showed mild atrophic gastritis and barium enema was normal. Normal results were obtained for the following investigations: blood urea, serum uric acid, calcium, inorganic phosphate, acid and alkaline phosphatase, cholesterol, folate; liver function tests; VDRL, RPCFT, RA and LE latex, 